\title{
The high education of optical engineering in East China
}

Xu Liu, Xiangdong Liu, Xiaoping Wang, Jian Bai, Yuling Liu

Xu Liu, Xiangdong Liu, Xiaoping Wang, Jian Bai, Yuling Liu, "The high education of optical engineering in East China," Proc. SPIE 9289, 12th Education and Training in Optics and Photonics Conference, 92890T (17 July 2014); doi: 10.1117/12.2070286

Event: 12th Education and Training in Optics and Photonics Conference, 2013, Porto, Portugal 


\title{
The High Education of Optical Engineering in East China
}

\author{
Xu Liu, XiangDong Liu, XiaoPing Wang, Jian Bai and YuLing Liu \\ State Key laboratory of modern optical instrumentation, \\ Department of Optical Engineering, Zhejiang University, Hangzhou 310027, China
}

\begin{abstract}
The history and the development of the high education in the field of optical engineering in the area of East China will be presented in the paper. The overall situation of research and human resource training in optics and photonics will also be reviewed, it shows that China needs lots of talents and experts in this field to support the world optical industry in East China
\end{abstract}

Keywords: High education, optical engineering, optical Industry

\section{INTRODUCTION}

The high education in China has developed so fast since 1980's. After the culture revolution, China recovered his national university entrance examination, and the young peoples are active to joint the examination for entering the university to get high education. The number of university increases greatly in the last 30 year, from about 200 universities to the current about 2400 universities in China (see figure1). The new entrance students form 300 thousand to about 6.5 millions each year. About one third of young people after the high school studies can enter the university studies.

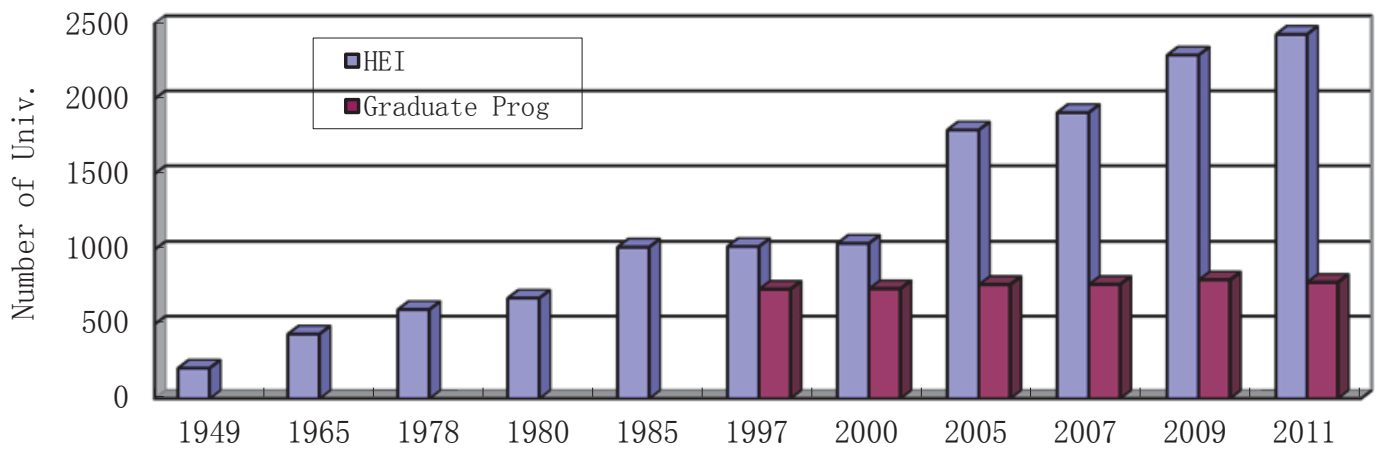

Figure.1 The number of university increases in the last 60 years in China [1]

There are about 244 disciplines in Chinese undergraduate program of the high education currently, among them optical engineering is one attractive discipline in China. Under this high speed progress of high education in China, the high education of optical engineering is also developed very fast, not only there are more and more universities are going to set up special discipline, or even department for optical engineering, but also many institutions have developed research group in this field. Because optics and photonics have played much more important role in the current information society, there are so many enterprises engaged in the East China in this field, and lots of engineers and workers involved in, and moreover there are several big research institute in optical engineering in this area. This makes the optical engineering as an interesting and hot discipline for a lot of universities. In the talk, we are going to give a review of the history of the high education of optical engineering in China, and current situation of optical engineering in the East China. 


\section{HISTORY OF HIGH EDUCATION IN OPTICAL ENGINEERING}

\subsection{The beginning}

The beginning of the optical engineering education and research was in 1952[2]. After the establishment of new China, the country economic development needed lots of engineer to develop the optical instruments which were eagerly required in the construction. The first discipline of optical instrumentation was set up in Zhejiang University in 1952, there are 30 students entering this program, and began the high education of Chinese optical engineering. In the same year, the first research Institute of optics and fine mechanics of Changchun was set up. The next year, the second optical instrument discipline was set up in The Beijing Institute of Technology. And then, form 1950's to 1960's, there are other four Universities : TianJing University, Changchun Institute of Optics and Fine Mechanics, Tsinhua Univesity and Nanjing University of Science \&Technology in china had set up their own discipline in optical instrumentation.

And in 1960, Zhejiang University has found the first Department of optical Instrumentation in China, and there were about 50 faculty members and 200 students in the department. During the late 1960's to the middle of 1970's, because of culture revolution, China had almost stop its own high education system.

\subsection{The growth}

After 1977, Chinese high education system recovered. For the Chinese people, to study in the university is a dream for getting a good job and good carriers. Since then national university entrance examination becomes a most important event for all the Chinese young people and even for all Chinese family. During 1980's, one of the best period in Chinese high education, the optical engineering has also develop quickly, the education program had become more complete, lots of text books in this field had been published (before the 1970's, most of the textbooks were handwriting). The student number growth gradually. In 1978 the Department of optical engineering of Zhejiang University began the first post graduate program for Master degree in this discipline in China, and the first Doctor degree program in this field in China was began in 1984. During that period, there are three directions in the discipline of optical engineering: photography, applied optics and laser technology, corresponding to the most important industries at that time in China. During 1980's to 1900's, China came into a high speed development, lots of optical industries and the research institutes in China, required a lot of young engineers and researchers, this boots the high education in China growth quickly, and many universities has separate their Applied physics department to found the optical engineering discipline.

At the begin of 2000's, the ride of optical communication in the world promoted greatly the high education of optical engineering in Asia, in China, and even in the East China, Tongji University and Fudan university in Shanghai, and South east university, Nanjing University in Nanjing, China Jiliang University in Hangzhou had open their own department of optical engineering. So that East China currently becomes one of the most important areas for the education of optical engineering [2].

\section{CURRENT OPTICAL ENGINEERING EDUCATION IN EAST CHINA}

East China currently is the most active economic region in China, some time we also call it the Yangtze river delta region, its conclude Shanghai, Zhejiang Province and Jiangsu Province, the main cities in Yangtze river delta zone are Shanghai, Hangzhou, Suzhou, Nanjing and Wuxi etc. In this region, there are three big high tech industries zones: Kun Shang industrial zone, Suzhou industrial zone and Wuxi industrial zone located in this region, and the most important display companies, solar cell companies, nano tech companies are located in these industrial zones, for example: Samsung, LG, Sony, Philips, Foxconn group, AMD Technologies, Hitachi Instrument, Nokia Telecommunications, Seagate ect. Shanghai is the centre, and Hangzhou, Nanjing around it just one hour by train.

It is not only the most important economy region, and also optical industry zone in China, because this region is biggest optical comment mass production zone in the world, solar cell industry, optical fiber industries and solid lighting industry are also very important in this area. As one of the most important high education center, in this region there are more than 400 universities, among them there are four C9 universities: Zhejiang university, Shanghai Jiaotong university, Nanjing university and Fudan university.

As for optical engineering, in this region, there are Zhejiang University, Nanjing University, Nanjing University of science and technology, Tongji university, Fudan university, University of Shanghai for Science and technology, Suzhou university, China Jiliang university, Shanghai Jiaotong university, and Southeast university ect. had specific department or discipline for optical engineering, these make East china becomes as the most important high education area for optical engineering in China. 
In the same time, there are many research institutes of Chinese Academy of Science located in this region, especially some of them is the well know institute specialized in optics and photonics, such as Shanghai Institute of Optics and Fine Mechanics, Shanghai Astronomical Observatory, and Shanghai Institute of Technical Physic, etc, so that the high education of optical engineering in the east china becomes one of the most important region in China.

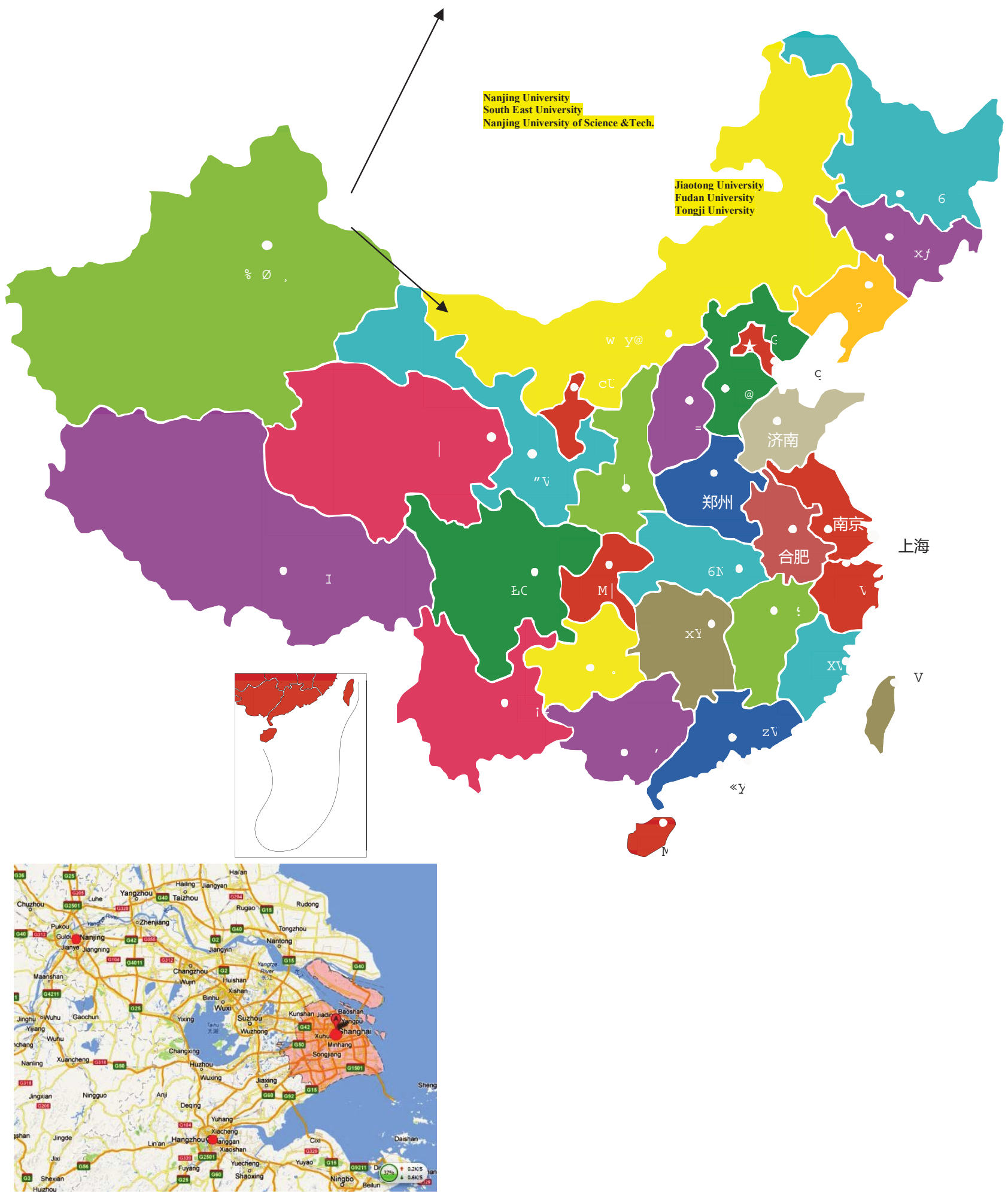

Figure 2 The main universities in East China (Shanghai, Hangzhou and Nanjing cities) 
Currently, the universities listed above can offer bachelor, master and most of them can provide $\mathrm{Ph} . \mathrm{D}$ degree in the discipline of Optical engineering. Table 1 shows the list of the course for the program of bachelor degree of optical engineering of Zhejiang university, you can find out that the optical engineering program covers very wide range.

Table 1 The list of the course for undergraduate program in Zhejiang University[3]

Credits required for graduation: $160+4+5$

Degree awarded: Bachelor of Engineering

\subsection{Fundamental Course}

(1) Required courses: 25 credits Calculus group, Linear Algebra group, Physics (A) group, Engineering Graphing are required .

(2) Fundamental elective course ( 22 credits)

\begin{tabular}{rlr}
\multicolumn{2}{c}{ Required courses: } & Credit \\
$061 \mathrm{~B} 0430$ & General Chemistry & 3.0 \\
$061 \mathrm{~B} 0422$ & Chemistry Lab & 1.0 \\
$061 \mathrm{~B} 0020$ & Complex Variable Functions \& Integral Transformation & 1.5 \\
$101 \mathrm{C} 0080$ & Electric Circuit Principles & 3.0 \\
$101 \mathrm{C} 0130$ & Basics of Digital Electronic Technology & 3.0 \\
$101 \mathrm{C} 0090$ & Lab for Electric Circuit Principles & 1.0 \\
$101 \mathrm{C} 0140$ & Lab for Digital Electronic Technology & 1.0 \\
$061 \mathrm{~B} 0090$ & Partial Differential Equations & 2.0 \\
$061 \mathrm{~B} 9090$ & Probability and Statistics & 2.5 \\
$101 \mathrm{C} 0110$ & Basics of Analogy Electronic Technology & 3.0 \\
$101 \mathrm{C} 0120$ & Lab for Analogy Electronic Technology & 1.0
\end{tabular}

\subsection{Professional courses 65.5 Credits}

(1) Required courses 28 credits

11120152 Basics of Computer Software 2.0

11120800 Applied Optics * $\quad 4.0$

$111 \mathrm{C} 0062$ Signals and Systems(B)* 3.0

$111 \mathrm{C} 0070$ Lab Work for Signals and Systems * 0.5

11120200 Interface \& Microprocessor * 3.5

11120790 Physical Optics * $\quad 5.0$

11120951 Embeded System and Application $\quad 2.5$

11120071 Optoelectronics * 3.0

11120750 Optoelectric Detection and System * $\quad 2.5$

11120090 Synthetic lab on Optical system * 2.0

(2) Limited option Courses ( 8 credits)

11120840 Optoelectric Precision Structure Design 2.5

11120900 Optical Materials \& Components Fabrication $\quad 2.0$

11192241 Thin film Optics and Technology 1.0

11120910 Optical system CAD 2.5

11120080 Optical communication Technology 2.5

11120880 Basics of Optical Networks $\quad 1.0$

11120930 Integrated Optoelectronic Devices and Designs $\quad 2.0$

11120890 Fiber Communications CAD 2.5 


$\begin{array}{llc}\text { (3 } & \text { Elective courses } & \\ 1 & \text { Basic knowledge } & \\ 11121560 & \text { Digital signal processing } & 2.0 \\ 11121090 & \text { Principles of Modern Communications } & 2.5 \\ 11121400 & \text { Electromagenetic waves and Applications } & 2.0 \\ 11120860 & \text { Basics of Quantum Optics } & 1.0 \\ 11121410 & \text { Introduction to Advanced Photonics } & 1.5 \\ 2-\text { Technique } & & \\ 11120780 & \text { Data Communication and Computer Network } & 2.0 \\ 11120960 & \text { Vision and Biophotonics } & 2.0 \\ 11120851 & \text { Introduction to Optical Engineering and Photonics } & 1.5 \\ 11590080 & \text { Opto-electronic Display technology } & 2.0 \\ 11194210 & \text { Color Science and Engineering } & 2.0 \\ 11121200 & \text { Microprocessors System Design and Application } & 2.5 \\ 11120870 & \text { Optical Spectroscopy and Applications } & 2.0 \\ 11121210 & \text { Modern Optical CAD Technology } & 2.0 \\ 11121220 & \text { Interferometry and Applications } & 2.0 \\ 11192260 & \text { Laser Technology and Application } & 2.0 \\ 11121420 & \text { Fiber Sensing Technology and Application } & 2.0 \\ 11590090 & \text { Modern Imaging System } & 2.0\end{array}$

Meanwhile, the different universities has different task for the student education, because, in China different universities has very different enrollment scores of national entrance examination, for example, the difference between C9 university with the general university will be 100 points (the total score is around $650-700$ point), so that the student can entering the C9 universities will be very good student, around top of 100 students, these students will be well educated in the C9 universities, and major of them after graduation are continue the master program and $\mathrm{PhD}$ program or going aboard for continue study. For the students in general university, there are just $10 \%$ of students going to continue study, and most part of them are going to work after graduate. Therefore the undergraduate programs for different Chinese universities are quite different, some of them more focus on solid fundamental knowledge education, and the other more focus on practical technique education.

In this region, there are about 5000 undergraduate students engage on optical engineering, and more than 1000 master degree candidates and about $400 \mathrm{PhD}$ candidates.

We would like to use the program of master degree and $\mathrm{PhD}$ degree of Zhejiang University to act as an example for presenting the overall situation of Chinese optical engineering high education. In China, we have 4 years undergraduate program for bachelor degree, and then 2 and half years for master degree, and then 3 years for $\mathrm{PhD}$ degree. It also possible for the good student can entering 5 years program for $\mathrm{PhD}$ degree just after the bachelor degree. It requires 170 credit point to graduate for Bachelor degree, 30 credits +Master's thesis for Master degree, 17 credits + Doctor's thesis for $\mathrm{PhD}$. The difference is in Master degree comparing with European education system.

\section{CONCLUSION}

In conclusion, the high education of optical engineering in China has a very complete program form bachelor degree to $\mathrm{PhD}$ degree for the young talents. The huge engineer requirement of the strong industry in the East China offers us a great opportunity to develop our own engineering education system. Even though we have many universities in East China, provide the optical engineering program, but because there are so many students concerning with the discipline, and they have different carrier plane, it needs our work harder to improve our education program, and make the education system more effective for the different requirement of the society and the young talents. 


\section{REFERENCES}

[1] http://www.moe.edu.cn/publicfiles/business/htmlfiles/moe/s7255/list.html

[2] Liu X., Zhang X.J. and Wang J.R., [The progress of high education and industry of optical engineering in East Asia ], Zhejiang University Publishers, Hangzhou, 241-248 (2009).

[3] http://opt.zju.edu.cn/

Proc. of SPIE Vol. 9289 92890T-6

Downloaded From: https://www.spiedigitallibrary.org/conference-proceedings-of-spie on 26 Apr 2023 Terms of Use: https://www.spiedigitallibrary.org/terms-of-use 